\title{
Biological Control of Damping Off of Okra caused by Rhizoctonia solani
}

\author{
Jaina V. Patel*, Amar Singh, Khushwinder Kaur, Divya Bhandhari and D. K. Banyal \\ Department of Plant Pathology, CSK Himachal Pradesh Krishi Vishvavidyalaya, \\ Palampur- 176 062, Himachal Pradesh, India \\ *Corresponding author
}

\section{A B S T R A C T}

\section{Keywords}

Okra, Damping off, Rhizoctonia solani, Biological control agent

\section{Article Info}

Accepted:

16 November 2019

Available Online:

10 December 2019
Damping off of okra is known to occur worldwide and caused by different pathogens under variable climatic conditions.. In Himachal Pradesh Rhizoctonia solani was found major associated pathogen with damping off of okra in summer season grown crop. Twenty isolates of Trichoderma spp. isolated from different rhizosphere soil and five standard isolates of Trichoderma spp. already available were evaluated for their antagonistic activity in vitro against $R$. solani. Among all the isolates tested, Trichoderma sp. -2 was found best bioagents for inhibiting mycelial growth of $R$. solani (67.8\%) in dual culture followed by Trichoderma sp.-9 (67.0\%), Trichoderma sp. -6 (64.8\%) and Trichoderma sp. -11(61.9\%). Significantly, maximum mycelial growth inhibition (42.4\%) of pathogen was with volatile compounds activity of Trichoderma sp.-2 while, filter sterilized culture filtrate of Trichoderma sp. -6 showed maximum pathogen mycelial inhibition. On the basis of morpho-cultural characteristics the potential bioagent isolates, Trichoderma sp.-6 and Trichoderma sp.-9 were identified as T. harzianum and T. viride, respectively. In mycoparasitic interaction, bioagents hyphae coiled around $R$. solani mycelium and after penetration lysed the pathogen hyphae. Under net house conditions, seed biopriming application method of bioagents was found superior for management of damping off of okra caused by $R$. solani than soil application, seed treatment and drenching.

\section{Introduction}

Okra (Abelmoschus esculentus L.) is an important vegetable crop belongs to Malvaceae family usually grown in summer as well as rainy season in almost all parts of India. Okra is affected by several diseases viz., cercospora leaf spot (Cercospora malayensis), wilt (Fusarium oxysporum f. sp. vasinfectum), powdery mildew (Erysiphe cichoracearum), anthracnose (Colletotrichum gloeosporioides), pod rot (Botrytis spp.), root rot (Rhizoctonia solani), damping off (Pythium spp.), viral disease like yellow vein mosaic and bacterial disease like leaf spot (Xanthomonas esculenti) but damping off is one of the major destructive diseases. Damping off of okra is known to occur worldwide and caused by Pythium spp. (Jukte et al., 2016), Phytophthora nicotianae (Matny, 2013), 
Rhizoctonia solani and Macrophomina phaseolina (Jiskani et al., 2007) under variable climatic conditions. Damping off of okra caused by soil borne pathogens has presently emerged one of the most important and destructive diseases of okra responsible for heavy losses in initial plant stand in the field particularly in summer grown crop. The reported pathogens associated with damping off have ability to survive as saprophyte in soil, perpetuate with resting structure and having wide host range. These attributes of pathogens have enabled the disease very difficult to manage with cultural, host resistance and chemical means. Soil borne pathogens can be managed successfully with the use of bioagents. Thus, biological control of damping off of okra can be one of alternative approach. Biological control agents (BCAs) can be highly specific and have different modes of action such as competition for space, nutrients and antibiosis. Suppression of pathogens have been reported due to volatile, non-volatile compounds of BCAs, degradation of cell wall by degrading enzymes like chitinase, $\beta-1,3$ glucanase, lipase results in lyses of cell wall and activate induced systemic resistance (ISR) (Junaid $e t$ al., 2013). So, in present investigation Trichoderma spp. were isolated from okra rhizosphere soil, screened in vitro against dominant pathogen $R$. solani and potential strains were in vivo evaluated for the management of damping off.

\section{Materials and Methods}

\section{Isolation and identification of pathogen(s) associated with damping off of okra}

Okra fields were visited during summer months (April -June) in different locations of Kangra district in 2018 and 2019. Diseased plants of okra showing typical symptoms of damping off at seedling stage were collected and brought to the laboratory for studying associated causal pathogen. Isolation was done from diseased samples. Later fungal colony arising from single hypha of each isolate was multiplied on PDA medium and used for further studies.

Pathogenicity test of isolated pathogen ( $R$. solani) was done by mixing 12 days old inoculum prepared on sterilized sand-wheat meal (8:2) medium (Sharma, 2011) at the rate $100 \mathrm{~g} / \mathrm{kg}$ in sterilized soil. Ten apparent healthy and surface sterilized seeds of susceptible okra variety P-8 were sown in each sick pot. Seeds sown in a pot having only sterilized soil were served as check. The pathogen was re-isolated from the diseased plant and cultured by standard methods discussed previously. The characteristics of pathogen culture thus obtained were compared with that of corresponding inoculated isolate of the pathogen to prove the pathogenicity. The most aggressive $R$. solani culture form Kangra was used for further studies.

The pathogen was identified by studying mycelial colour, diameter and constriction at the branching point, sclerotia size and colour on PDA

\section{Isolation of Trichoderma spp. from rhizosphere soil}

Isolation of Trichoderma spp. from okra rhizosphere soil samples, a serial dilution plate technique was followed. In this method, $10 \mathrm{~g}$ of soil was transferred in $100 \mathrm{ml}$ of sterile distilled water and contents were mixed thoroughly by shaking for five minutes. Ten $\mathrm{ml}$ of aliquot was drawn and transferred to 90 $\mathrm{ml}$ of sterile distilled water. The suspension was shaken for one minute before it was further diluted. Further, dilutions till $10^{-4}$ to $10^{-6}$ were obtained and $1 \mathrm{ml}$ of suspension from respective dilutions were transferred aseptically into Petri plates containing PDA medium and incubated at $25 \pm 1^{\circ} \mathrm{C}$ for five days 
for the development of the colonies. Three replications were maintained for each dilution. Mycelial growth from such colonies was subculture on agar slants.

\section{Dual culture technique}

Twenty fungal antagonists obtained from okra rhizosphere soil were evaluated by dual culture technique against Rhizoctonia solani. Five $\mathrm{mm}$ discs of antagonist and pathogen were co-inoculated $7 \mathrm{~cm}$ apart on PDA plates and incubated at $25 \pm 1^{\circ} \mathrm{C}$ for 5 days.

In control, only a disc of pathogen was inoculated. Whole of experiment was carried out in triplicates. Percent growth inhibition was determined by Vincent, (1947) formula:

Per cent growth inhibition

$=$ Growth $(\mathrm{mm})-$ Growth $(\mathrm{mm}) \times 100$

in control in treatment

Growth (mm) in control

Four bioagent isolates which exhibited significantly high inhibition of $R$. solani in vitro were further studied.

\section{Morphological identification of potential bioagents}

Two per cent malt extract agar Petri plates were inoculated in the centre with a $5 \mathrm{~mm}$ mycelial disc taken from pure culture of the isolates and incubated at $21 \pm 1^{\circ} \mathrm{C}$ for 4 days.

Each isolate was examined daily and colony cultural characters such as aroma and pigmentation on media were recorded.

Examination of the size and shape of conidia and phialide provided a tentative identification of Trichoderma spp. under a light microscope and compared with keys given by (Kubicek and Harman, 1998).

\section{Mycoparasitism of biocontrol agent(s) on pathogen}

The interactions between different bioagents and $R$. solani were studied in vitro using slide culture method (Bhat, 2017) to avoid the disturbance caused to the interacting mycelium while removing from the interaction zone in dual culture Petri plates.

In this method, pathogen and antagonist were grown as dual culture on a sterilized glass slide kept in a sterilized Petri plate chamber on PDA by keeping $3 \mathrm{~mm}$ bits each of pathogen and the antagonist $3 \mathrm{~cm}$ apart and incubated for 3 days at $25 \pm 1^{\circ} \mathrm{C}$. Three replicates were maintained for each bioagent. When contact zone developed, the slide was taken out from Petri plate and stain with lactophenol cotton blue and viewed directly under microscope for hyphal interaction between the bioagent and host fungus.

Effect of volatile and non volatile compounds of bioagents against Rhizoctonia solani

Growth inhibition of pathogens by nonvolatile compounds released by Trichoderma species

The effect of volatile compounds released by Trichoderma species was evaluated by 'invert plate technique'(Dennis \& Webster, 1971b).

The PDA plates were inoculated with $5 \mathrm{~mm}$ mycelial discs of 3 days old growing culture of Trichoderma isolates. The lid of each plate was replaced with the bottom of other plate inoculated with $5 \mathrm{~mm}$ mycelial discs of pathogen. Both plates were sealed together with adhesive tape (parafilm) and incubated at $25 \pm 1^{\circ} \mathrm{C}$ for 5 days. Control treatment did not contain Trichoderma isolate. Percent growth inhibition was determined by Vincent, (1947) formula. 
Effect of non-volatile compounds of bioagents against Rhizoctonia solani

Growth inhibition of pathogens by nonvolatile compounds released by Trichoderma species

Poisoned food technique (Nene and Thapliyal, 1993) was followed to evaluate the effect of non-volatile compounds released by the Trichoderma spp. on the growth of $R$. solani. The Trichoderma spp. were grown in potato dextrose broth (PDB) assuming that the antagonist will utilize the nutrients from broth and release some non-volatile metabolites in the medium, which may affect the growth of pathogen. The culture filtrate was passed through Millipore $0.42 \mu$ filter paper using vacuum pump and the filtrate was collected in a sterilized flask.

Then half of the culture filtrate was sterilized by autoclaving and remaining half was kept un-sterilized for further studies. PDA amended with culture filtrate at final concentrations of 1:1 and 2:1 culture filtrate/ PDA (v/v). Petri plates were centrally inoculated with $5 \mathrm{~mm}$ discs of $R$. solani cut from 4 days old culture and incubated at $25 \pm 1{ }^{\circ} \mathrm{C}$ for 5 days. PDA plates not amended with culture filtrate and inoculated with the test pathogen were maintained as check. Per cent inhibition of the mycelial growth was calculated by formula given by Vincent, (1947).

\section{In vivo management of damping off of okra}

\section{Effect of different methods of application of potential antagonists on disease development in pots}

Soil was inoculated simultaneously with the mass cultured R. solani @ 100g/kg. Regular irrigation was provided to maintain adequate moisture necessary for development of antagonists and pathogen.

\section{Preparation of spore suspension}

Spore suspension was prepared by adopting the procedure of Singh et al., (2016). The culture of Trichoderma strains was grown separately on PDA plates for 7 days at $25 \pm 1{ }^{\circ} \mathrm{C}$. The spores were harvested individually by scraping the surface of the colonies with a spatula in sterilized saline water $(\mathrm{NaCl} 0.85 \%)$ and filtered with sterile muslin cloth. The spore suspension of each strain was centrifuged at $10,000 \mathrm{rpm}$ for 10 minutes. The pellet was resuspended in same volume of autoclaved 1.5 per cent CMC (Carboxymethyl cellulose).

\section{Seed treatment with potential bioagents}

Fifteen seeds of okra variety P-8 were immersed in spore suspension of each Trichoderma isolates for 30 minutes and sown in sick soil. Seeds soaked in distilled water kept as a control.

\section{Seed biopriming with potential bioagents}

The okra seeds were surface sterilized with 1.5 per cent sodium hypochlorite for 5 minutes, rinsed thrice with sterilized water and dried under laminar air flow on blotting paper.

Then, seeds soaked in the spore suspension for $4 \mathrm{hrs}$ and treated with CMC. Seeds treated with CMC only were used as control. The seeds were dried in laminar air flow for 2 hours and placed in germination sheets saturated with water and kept at $25 \pm 1^{\circ} \mathrm{C}$, maintained up to radicle emergence and then after sown in pots containing sick soil.

\section{Soil application with potential bioagents}

Trichoderma spp. were multiplied on FYM. For this purpose, FYM filled in flasks and autoclaved consecutively for 2 days. These flasks were then inoculated separately with 
each antagonist culture aseptically and kept in incubator at $25 \pm 1^{\circ} \mathrm{C}$ for 15 days.

\section{Drenching with potential bioagents}

The culture of Trichoderma strains was grown separately on PDA plates for 7 days at $25 \pm 1^{\circ} \mathrm{C}$. The spores were harvested individually by scraping the surface of the colonies with a spatula in distilled water. The spore suspension of each strain was centrifuged at $10,000 \mathrm{rpm}$ for 10 minutes. Seedling roots were treated with bioagents by drenching into soil in each pot.

\section{Results and Discussion}

Pathogen(s) associated with damping off of okra

Analysis for associated pathogens of the infected plants from different locations (Baijnath, Bhawarna, Palampur, Kangra and Nagrota) in Kangra district showed that Rhizoctonia solani was dominant pathogen and associated with damping off of okra. Out of total 404 samples evaluated, the frequency of $R$. solani associated with the disease was 71 per cent while $F$. solani was associated with 11 per cent samples from different locations. During summer season, prevalence of warm and dry conditions may be attributed to the dominance of $R$. solani as damping off causing agent (Plate 1). Diwakar et al., (1986) who also reported in India that damping off of okra caused by $R$. solani at early growth stage in the month of June-July from Konkan region of Maharashtra. Jandaik et al., (2015) observed that $F$. oxysporum, $R$. solani, Sclerotium rolfsii were associated pathogens with damping off and wilt affected plants of okra from Solan area of Himachal Pradesh. In Iraq recently, Jalal et al., (2019) reported that $R$. solani, $F$. solani and Macrophomina phaseolina were associated with damping off of okra.

\section{Identification of pathogen(s)}

The pathogen was identified as $R$. solani. A characteristic mycelium was observed under microscopic examination which had a small constriction at the base of the branch and the branches arise frequently at right angle from the parent mycelium. $R$. solani developed the light brownish to dark brown colour mycelium on PDA with small (less than $1 \mathrm{~mm}$ ) and brown to dark brown coloured sclerotia. It covered the $90 \mathrm{~mm}$ Petri plates in 3-4 days when kept at $25 \pm 1^{\circ} \mathrm{C}$. In microscopic study of fungal isolates which slowed colony growth with white mycelia revealed two types of macro and micro conidia. Macro conidia were slightly curved 3-5 septate and measured 30$40 \mathrm{X}$ 4.5-6.0 $\mu \mathrm{m}$ while micro conidia were spherical to oval and measured 8-15 x 2.0-4.0 $\mu \mathrm{m}$. It covered the $90 \mathrm{~mm}$ Petri plate in 7-8 days when kept at $25 \pm 1^{\circ} \mathrm{C}$.

Isolation of bioagents from rhizosphere and in vitro screening of antagonistic activity against Rhizoctonia solani

The antagonistic activity of different isolates of Trichoderma spp. viz., Trichoderma koningii (DMA-8), T. harzianum (SMA-5), $T$. koningii (JMA-11), T. viride, T. harzianum (TH-11) available from the Department of Plant Pathology and 20 isolates of Trichoderma sp. (I 1 to 20) isolated from okra rhizosphere soil were evaluated against $R$. solani in vitro by dual culture method and results on mycelial growth inhibition are presented in table 1 . The data revealed that all the isolates of Trichoderma spp. significantly inhibited the mycelial growth of $R$. solani. The mycelial growth inhibition of $R$. solani ranged from 22.2 to 67.8 per cent. Among all the isolates, Trichoderma sp. -2 proved to be the most effective strain that inhibited 67.8 per cent mycelial growth of $R$. solani followed by Trichoderma sp. -9 (67.0\%), Trichoderma sp. -6 (64.8\%) and Trichoderma sp. -11 (61.9\%). 
Trichoderma sp.-15 gave 22.2 per cent mycelial growth inhibition and proved to be least effective. Hence, four potential isolates were further studied for morpho-cultural identification, mechanisms of antagonism and management against $R$. solani causing damping off of okra. Kamala and Devi, (2012) also reported that 114 Trichoderma isolates inhibited growth of $R$. solani by dual culture method. Recently, Erayya Kumar et al., (2018) evaluated 25 Trichoderma isolates which inhibited growth of $R$. solani and other pathogens by dual culture method.

\section{Mycoparasitism between potential Trichoderma spp. and Rhizoctonia solani}

Mode of antagonism between potential Trichoderma isolates and $R$. solani was studied by slide culture technique. The microscopic examination revealed that hyphae of Trichoderma sp.-2, Trichoderma sp.-6, Trichoderma sp.-9 and Trichoderma sp.-11 coiled with the hyphae of $R$. solani and penetrated hyphae of test pathogen (Plate 2). Earlier Dennis and Webster, (1971c) reported that most of Trichoderma isolates coiled around different test fungi (Rhizoctonia solani, Fomes annosus, Fusarium oxysporum, Pyronema domesticum, Mucor hiemalis and Pythium ultimum) on 2 per cent malt extract agar in dual culture. Elad et al., (1983) reported mycoparasitic activity of $T$. harzianum and T. hamatum against Sclerotium rolfsii and $R$. solani under scanning electron microscopy. Trichoderma attach to host either by hyphal coils, hooks or appressoria.

\section{Morpho- cultural identification of potential bioagents}

On the basis of cultural characters, Trichoderma sp.-2 and Trichoderma sp.-9 was found to produce a typical smell resembling coconut and Trichoderma sp.-6 produce a smell resembling earthy. Colonies of Trichoderma sp.-6 produced diffusible yellow pigments in the medium thus PDA turn to yellowish in colour. The production of diffusible pigments was not found in other Trichoderma isolates. The microscopic features of Trichoderma isolates were observed under light microscope. light green and dark green coloured mature conidia observed in Trichoderma sp.-6 and Trichoderma sp.-9 on 2 per cent malt extract agar medium, respectively. Both Trichoderma sp.-6 and Trichoderma sp.-9 produce subglobose to obovoid shape conidia. Phialide shape in Trichoderma sp.-9 and Trichoderma sp.-6 was observed verticillate and lageniform and ampulliform to lageniform, respectively.

On the basis of morphological characters Trichoderma sp. isolate - 6 was identified as $T$. harzianum while, Trichoderma sp. isolate - 9 was identified as $T$. viride (Table 2).

Effect of volatile an dnon volatile metabolites of bioagents on Rhizoctonia solani

The volatile compounds released by Trichoderma spp. have also exerted inhibitory effect on the growth of the $R$. solani (Table 3). Perusal of data revealed that the potential isolates of Trichoderma spp. significantly affected the mycelial growth of $R$. solani. Among the tested isolates, Trichoderma sp. -2 had shown maximum inhibition of mycelial growth (42.4\%) followed by Trichoderma sp. -9 (39.3\%), Trichoderma sp. -6 (30.7\%) and Trichoderma sp. -11 (12.0\%). Many workers reported that Pseudomonas and different Trichoderma species inhibited the normal mycelial growth by production of volatile substances such as alkyl pyrones and several heteroaromatic compounds (Claydon et al., 1987; Michrina et al., 1995; Schalchli et al., 2011). 
Table.1 In vitro efficacy of bioagents against mycelial growth of Rhizoctonia Solani

\begin{tabular}{|c|c|c|}
\hline Bioagent isolates & $\begin{array}{c}\text { Mycelial growth }(\mathrm{mm}) \text { of } \\
\text { Rhizoctonia solani in dual culture }\end{array}$ & Per cent inhibition \\
\hline T. harzianum (TH-11) & 36.67 & $59.3(7.76) *$ \\
\hline T. koningii (JMA-11) & 37.67 & $58.2(7.69)$ \\
\hline T. koningii (DMA-8) & 37.00 & $58.9(7.74)$ \\
\hline T. viride & 34.33 & $61.9(7.93)$ \\
\hline T. harzianum (SMA-5) & 35.33 & $60.7(7.86)$ \\
\hline Trichoderma sp.- 1 & 39.33 & $56.3(7.57)$ \\
\hline Trichoderma sp.- 2 & 29.00 & $67.8(8.30)$ \\
\hline Trichoderma sp.- 3 & 43.33 & $51.9(7.27)$ \\
\hline Trichoderma sp.- 4 & 43.33 & $51.9(7.27)$ \\
\hline Trichoderma sp.- 5 & 45.00 & $50.0(7.14)$ \\
\hline Trichoderma sp.- 6 & 31.67 & $64.8(8.11)$ \\
\hline Trichoderma sp.- 7 & 43.33 & $51.9(7.23)$ \\
\hline Trichoderma sp.- 8 & 42.33 & $53.0(7.34)$ \\
\hline Trichoderma sp.- 9 & 29.67 & $67.0(8.25)$ \\
\hline Trichoderma sp.-10 & 42.33 & $53.0(7.35)$ \\
\hline Trichoderma sp.-11 & 34.33 & $61.9(7.93)$ \\
\hline Trichoderma sp.-12 & 44.67 & $50.4(7.17)$ \\
\hline Trichoderma sp.-13 & 58.00 & $35.7(6.04)$ \\
\hline Trichoderma sp.-14 & 46.67 & $48.2(7.01)$ \\
\hline Trichoderma sp.-15 & 70.00 & $22.2(4.81)$ \\
\hline Trichoderma sp.-16 & 48.33 & $46.3(6.89)$ \\
\hline Trichoderma sp.-17 & 63.33 & $29.6(5.53)$ \\
\hline Trichoderma sp.-18 & 49.33 & $45.2(6.80)$ \\
\hline Trichoderma sp.-19 & 61.33 & $31.9(5.73)$ \\
\hline Trichoderma sp.-20 & 45.00 & $50.0(7.14)$ \\
\hline Control & 90.00 & $0.0(1.00)$ \\
\hline $\mathrm{CD}(\mathrm{p}=0.05)$ & 3.693 & 0.293 \\
\hline
\end{tabular}

* The figures in parentheses are square root transformed values 
Table.2 Morpho-cultural identification of potential bioagents

\begin{tabular}{|c|c|c|c|c|c|}
\hline Isolates & Aroma & $\begin{array}{c}\text { Reverse } \\
\text { colour on } \\
\text { Petri plate }\end{array}$ & $\begin{array}{l}\text { Conidia size (um) } \\
\text { and shape }\end{array}$ & $\begin{array}{l}\text { Phialide size (um) } \\
\text { and shape }\end{array}$ & Identification \\
\hline $\begin{array}{l}\text { Trichoderma } \\
\text { sp.-6 }\end{array}$ & Earthy & Yellowish & $\begin{array}{l}\text { Size- } 2.7-3.5 \times 2.1- \\
2.6 \\
\text { Shape-Sub globose } \\
\text { to obovoid, smooth } \\
\text { walled and } \\
\text { sub-hyaline to pale } \\
\text { green }\end{array}$ & $\begin{array}{c}\text { Size- } 3.5-7.5 \times 2.5- \\
3.8 \\
\text { Shape- } \\
\text { Ampulliform to } \\
\text { lageniform }\end{array}$ & $\begin{array}{l}\text { Trichoderma } \\
\text { harzianum }\end{array}$ \\
\hline $\begin{array}{l}\text { Trichoderma } \\
\text { sp.- } 9\end{array}$ & Coconut & No colour & $\begin{array}{c}\text { Size- } 2.6-3.8 \times 2.2- \\
3.4 \\
\text { Shape- dark green } \\
\text { colour, smooth } \\
\text { walled and Sub } \\
\text { globose at maturity }\end{array}$ & $\begin{array}{c}\text { Size- } 6.0- \\
12.0 \times 2.4-3.0 \\
\text { Shape-Verticillate } \\
\text { and more or less } \\
\text { lageniform }\end{array}$ & $\begin{array}{l}\text { Trichoderma } \\
\text { viride }\end{array}$ \\
\hline $\begin{array}{l}\text { Trichoderma } \\
\text { sp.-2 }\end{array}$ & Coconut & No colour & $\begin{array}{c}\text { Size- } 4.8 \times 4.8 \\
\text { Shape- globose, } \\
\text { dark green and } \\
\text { smooth walled }\end{array}$ & $\begin{array}{c}\text { Size-3.5-7.27×2.5- } \\
3.03 \\
\text { Shape-Verticillate, } \\
\text { narrow } \\
\text { ampulliform or } \\
\text { lageniform }\end{array}$ & - \\
\hline $\begin{array}{l}\text { Trichoderma } \\
\text { sp.-11 }\end{array}$ & Absent & No colour & $\begin{array}{c}\text { Size- } 2.7 \times 2.7 \\
\text { Shape-globose, } \\
\text { smooth walled and } \\
\text { green to dull green }\end{array}$ & $\begin{array}{c}\text { Size- } 6.0- \\
10.0 \times 2.5-3.5 \\
\text { Shape- } \\
\text { Ampulliform to } \\
\text { lageniform }\end{array}$ & - \\
\hline
\end{tabular}

Table.3 In vitro efficacy of volatile metabolites of bioagents against mycelial growth of Rhizoctonia solani

\begin{tabular}{|c|c|c|}
\hline Biocontrol agent & Mycelial growth $(\mathbf{m m})$ & Per cent inhibition \\
\hline Trichoderma sp. $\mathbf{- 2}$ & 51.8 & $42.4(6.60)$ \\
\hline Trichoderma sp. $\mathbf{- 6}$ & 62.4 & $30.7(5.63)$ \\
\hline Trichoderma sp. $\mathbf{- 9}$ & 54.6 & $39.3(6.35)$ \\
\hline Trichoderma sp. $\mathbf{- 1 1}$ & 79.2 & $12.0(3.60)$ \\
\hline Control & 90.0 & $0.0(1.00)$ \\
\hline CD $(\mathbf{p = 0 . 0 5 )}$ & 1.188 & 0.125 \\
\hline
\end{tabular}

* The figures in parentheses are square root transformed value 
Table.4 In vitro efficacy of non-volatile metabolites in autoclaved sterilized and filter sterilized culture filtrates of bioagents against mycelial growth of Rhizoctonia solani

\begin{tabular}{|c|c|c|c|c|c|c|c|c|}
\hline \multirow[t]{3}{*}{ Biocontrol agent } & \multicolumn{4}{|c|}{ Autoclaved sterilized culture filtrate } & \multicolumn{3}{|c|}{ Filter sterilized culture } & filtrate \\
\hline & \multicolumn{2}{|c|}{$\begin{array}{c}\text { Mycelial growth } \\
(\mathbf{m m})\end{array}$} & \multicolumn{2}{|c|}{ Per cent inhibition } & \multicolumn{2}{|c|}{$\begin{array}{l}\text { Mycelial growth } \\
(\mathbf{m m})\end{array}$} & \multicolumn{2}{|c|}{ Per cent inhibition } \\
\hline & 1:1 & $2: 1$ & $1: 1$ & $2: 1$ & $1: 1$ & $2: 1$ & $1: 1$ & $2: 1$ \\
\hline Trichoderma sp.-2 & 90.0 & 84.8 & 0.0 & $\begin{array}{c}5.8 \\
(2.60) *\end{array}$ & 79.4 & 65.6 & $\frac{11.8}{(3.57) *}$ & $\begin{array}{c}27.1 \\
(5.30) *\end{array}$ \\
\hline Trichoderma sp.- 6 & 90.0 & 80.0 & 0.0 & $\begin{array}{c}11.1 \\
(3.48)\end{array}$ & 41.2 & 34.0 & $\begin{array}{c}54.2 \\
(7.43)\end{array}$ & $\begin{array}{c}62.2 \\
(7.95)\end{array}$ \\
\hline Trichoderma sp.- 9 & 90.0 & 81.0 & 0.0 & $\begin{array}{c}10.0 \\
(3.31)\end{array}$ & 52.0 & 51.0 & $\begin{array}{c}42.2 \\
(6.57)\end{array}$ & $\begin{array}{c}43.3 \\
(6.66)\end{array}$ \\
\hline Trichoderma sp.-11 & 90.0 & 81.2 & 0.0 & $\begin{array}{c}9.8 \\
(3.28)\end{array}$ & 64.0 & 51.6 & $\begin{array}{c}28.9 \\
(5.47)\end{array}$ & $\begin{array}{c}42.7 \\
(6.61)\end{array}$ \\
\hline Control & 90.0 & 90.0 & - & - & 90.0 & 90.0 & $\begin{array}{c}0.0 \\
(1.00)\end{array}$ & $\begin{array}{c}0.0 \\
(1.00)\end{array}$ \\
\hline $\mathrm{CD}(\mathrm{p}=\mathbf{0 . 0 5})$ & & 1.246 & & 0.217 & 1.260 & 1.792 & 0.138 & 0.156 \\
\hline
\end{tabular}

* The figures in parentheses are square root transformed value 
Table.5 Biological control of damping off of okra with seed treatment and biopriming of potential bioagents

\begin{tabular}{|c|c|c|c|c|c|c|c|c|c|c|c|c|}
\hline & \multicolumn{6}{|c|}{ Seed treatment } & \multicolumn{6}{|c|}{ Biopriming } \\
\hline Bioagents & $\begin{array}{c}\text { Seed } \\
\text { germination } \\
(\%)\end{array}$ & $\begin{array}{l}\text { Pre- } \\
\text { emergence } \\
(\%)\end{array}$ & $\begin{array}{c}\text { Disease } \\
\text { control } \\
(\%)\end{array}$ & $\begin{array}{c}\text { Post- } \\
\text { emergence } \\
(\%)\end{array}$ & $\begin{array}{c}\text { Disease } \\
\text { control } \\
(\%)\end{array}$ & $\begin{array}{l}\text { Seedling } \\
\text { stand }(\%)\end{array}$ & $\begin{array}{l}\text { Seed germination } \\
(\%)\end{array}$ & $\begin{array}{l}\text { Pre- } \\
\text { emergence } \\
(\%)\end{array}$ & $\begin{array}{c}\text { Disease } \\
\text { control } \\
(\%)\end{array}$ & $\begin{array}{c}\text { Post- } \\
\text { emergence } \\
(\%)\end{array}$ & $\begin{array}{c}\text { Disease } \\
\text { control } \\
(\%)\end{array}$ & $\begin{array}{l}\text { Seedling } \\
\text { stand }(\%)\end{array}$ \\
\hline $\begin{array}{l}\text { Trichoder } \\
\text { ma sp.- } 2\end{array}$ & 66.7 & 33.3 & 37.5 & 39.1 & 36.2 & 41.7 & 81.7 & 18.3 & 64.5 & 22.7 & 61.6 & 63.3 \\
\hline $\begin{array}{l}\text { Trichoder } \\
\text { ma sp.- } 6\end{array}$ & 61.7 & 38.3 & 28.1 & 54.7 & 10.7 & 28.3 & 73.3 & 26.7 & 48.4 & 21.0 & 64.5 & 58.3 \\
\hline $\begin{array}{l}\text { Trichoder } \\
\text { ma sp.- } 9\end{array}$ & 65.0 & 35.0 & 34.4 & 52.7 & 14.0 & 31.7 & 78.3 & 21.7 & 58.1 & 18.9 & 68.1 & 63.3 \\
\hline $\begin{array}{l}\text { Trichoder } \\
\text { ma sp.-11 }\end{array}$ & 55.0 & 45.0 & 15.6 & 58.3 & 4.9 & 21.7 & 66.7 & 33.3 & 35.5 & 29.3 & 50.4 & 48.3 \\
\hline $\begin{array}{l}\text { Control } \\
\text { (with } \\
\text { pathogen) }\end{array}$ & 46.7 & 53.3 & - & 61.3 & - & 18.3 & 48.3 & 51.7 & & 59.1 & & 20.0 \\
\hline $\begin{array}{c}\text { Control } \\
\text { (without } \\
\text { pathogen) }\end{array}$ & 91.7 & 8.3 & - & - & - & 91.7 & 91.7 & 8.3 & & - & & 91.7 \\
\hline $\begin{array}{c}\text { CD } \\
(p=0.05)\end{array}$ & 14.00 & 2.21 & & 2.45 & & & 10.01 & 2.31 & & 2.29 & & \\
\hline
\end{tabular}


Table.6 Biological control of damping off of okra with soil and drenching application of potential bioagents

\begin{tabular}{|c|c|c|c|c|c|c|c|c|c|c|c|c|}
\hline \multirow[b]{2}{*}{ Bioagents } & \multicolumn{6}{|c|}{ Soil application } & \multicolumn{6}{|c|}{ Drenching } \\
\hline & $\begin{array}{c}\text { Seed } \\
\text { germination } \\
(\%)\end{array}$ & $\begin{array}{l}\text { Pre- } \\
\text { emergence } \\
(\%)\end{array}$ & $\begin{array}{c}\text { Disease } \\
\text { control } \\
(\%)\end{array}$ & $\begin{array}{l}\text { Post- } \\
\text { emergence } \\
(\%)\end{array}$ & $\begin{array}{c}\text { Disease } \\
\text { control } \\
(\%)\end{array}$ & $\begin{array}{l}\text { Seedling } \\
\text { stand } \\
(\%)\end{array}$ & $\begin{array}{c}\text { Seed } \\
\text { germination } \\
(\%)\end{array}$ & $\begin{array}{l}\text { Pre- } \\
\text { emergence } \\
(\%)\end{array}$ & $\begin{array}{c}\text { Disease } \\
\text { control } \\
(\%)\end{array}$ & $\begin{array}{l}\text { Post- } \\
\text { emergence } \\
(\%)\end{array}$ & $\begin{array}{c}\text { Disease } \\
\text { control } \\
(\%)\end{array}$ & $\begin{array}{l}\text { Seedling } \\
\text { stand } \\
(\%)\end{array}$ \\
\hline $\begin{array}{c}\text { Trichoderma } \\
\text { sp.- } 2\end{array}$ & 76.7 & 23.3 & 56.3 & 29.2 & 52.4 & 55.0 & 46.7 & 53.3 & 0.0 & 53.0 & 13.6 & 25.0 \\
\hline $\begin{array}{l}\text { Trichoderma } \\
\text { sp.- } 6\end{array}$ & 71.7 & 28.3 & 46.9 & 33.5 & 45.4 & 46.7 & 46.7 & 53.3 & 0.0 & 57.7 & 5.8 & 26.7 \\
\hline $\begin{array}{c}\text { Trichoderma } \\
\text { sp.- } 9\end{array}$ & 65.0 & 35.0 & 34.4 & 52.6 & 14.1 & 31.7 & 46.7 & 53.3 & 0.0 & 60.3 & 1.7 & 26.7 \\
\hline $\begin{array}{c}\text { Trichoderma } \\
\text { sp.-11 }\end{array}$ & 56.7 & 41.7 & 21.9 & 58.0 & 5.4 & 20.0 & 46.7 & 53.3 & 0.0 & 53.6 & 12.6 & 20.0 \\
\hline $\begin{array}{c}\text { Control } \\
\text { (with } \\
\text { pathogen) }\end{array}$ & 46.7 & 53.3 & - & 61.3 & - & 18.3 & 46.7 & 53.3 & & 61.3 & & 28.3 \\
\hline $\begin{array}{c}\text { Control } \\
\text { (without } \\
\text { pathogen) }\end{array}$ & 91.7 & 8.3 & - & - & - & 91.7 & 91.7 & 8.3 & & & & 91.7 \\
\hline
\end{tabular}


Plate.1 Damping off symptoms of infected okra seedlings collected from different locations in Kangra district
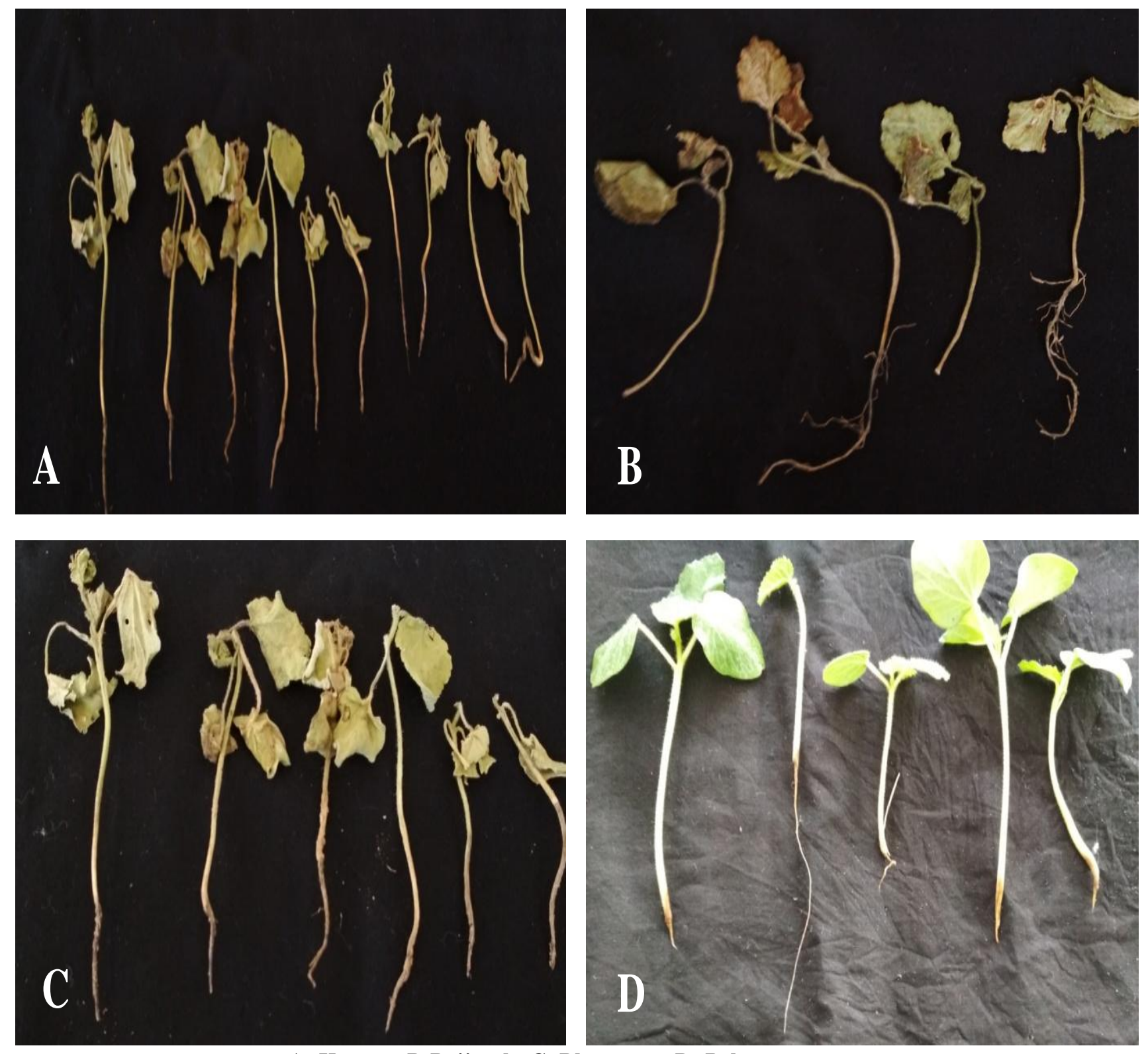

A- Kangra; B-Baijnath; C- Bhawarna; D- Palampur 
Plate.2 Mycoparasitic interaction between Rhizoctonia solani and potential bioagents
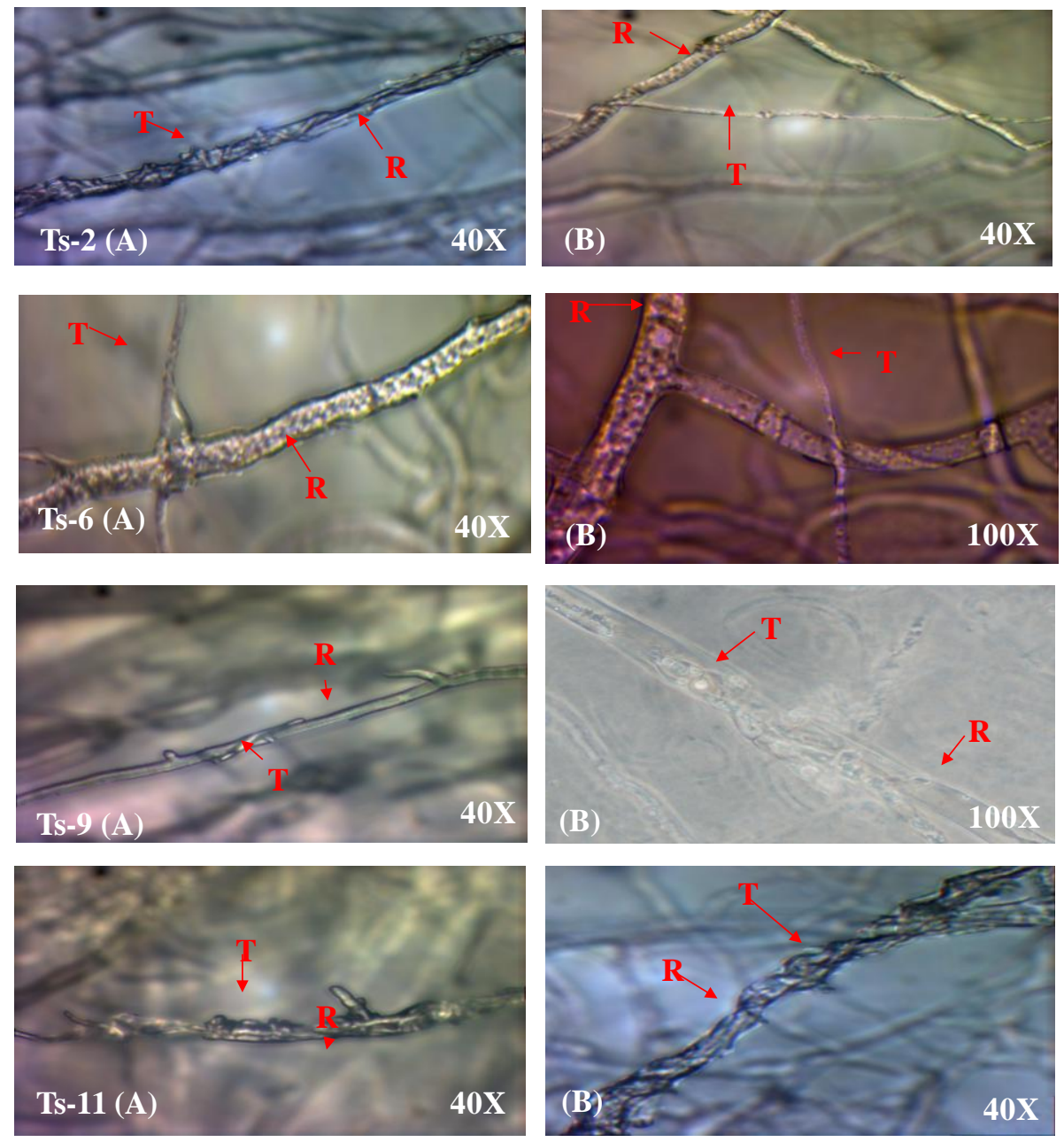

Ts-2 - Trichoderma sp.-2; Ts-6 - Trichoderma sp.-6

Ts-9 - Trichoderma sp.-9; Ts-11- Trichoderma sp.-11

A- Coiling ; B-Penetration

Effect of non-volatile metabolites of bioagents on Rhizoctonia solani

The growth inhibition of $R$. solani by autoclaved and filter sterilized culture filtrate of Trichoderma spp. is presented in table 4. The data on inhibition of mycelial growth of $R$. solani obtained at two ratios $(1: 1$ and $2: 1)$ of autoclaved sterilized and filter sterilized filtrate revealed that all the tested isolates of Trichoderma spp. though significantly inhibited the mycelial growth of $R$. solani but comparatively less than filter sterilized.
Autoclaved sterilized culture filtrates at 1:1 ratio did not have any impact on the radial growth of fungus however, at 2:1 ratio Trichoderma sp. -6 exhibited maximum mycelial inhibition (11.1\%) followed by Trichoderma sp. -9 (10.0\%). Filter sterilized culture filtrate of Trichoderma sp. -6 resulted in maximum mycelial inhibition of 54.2 and 62.2 followed by Trichoderma sp. -9 inhibited 42.2 and 43.3 per cent at 1:1 and 2:1 ratio, respectively. Our results were in accordance with several workers who have also found inhibition of mycelial growth by cultural 
filtrates of various bioagents (Kucuk and Kivanc, 2003; Raut et al., 2014 and Tapwal et al., 2015).

\section{Evaluation of potential bioagents for management of damping off of okra}

The Trichoderma spp. isolates found as most potential antagonist against $R$. solani under in vivo screening were evaluated for the management of damping off through the application of bioagents as, seed treatment, soil application, seed biopriming and drenching under net house conditions and had shown significant reduction in pre and postemergence damping off of okra (Table 5 and $6)$.

Among all the treatments, Trichoderma sp.-2 was significantly superior for controlled preemergence damping off, 64.5, 56.3 and 37.5 per cent when applied as biopriming, soil application, seed treatment, respectively followed by Trichoderma sp.-9 controlled 58.1 and 34.4 per cent disease when applied as biopriming and seed treatment, respectively and Trichoderma sp.-6 controlled 46.9 per cent disease when applied as soil application.

Post- emergence damping off highest controlled $(68.1 \%)$ by Trichoderma sp.-9 when applied as biopriming followed by Trichoderma sp.-2 controlled disease upto 52.4, 36.2 and 13.6 per cent when applied as soil application, seed treatment and drenching followed by Trichoderma sp.-6 controlled disease upto 64.5 and 45.4 per cent when applied as biopriming and soil application and Trichoderma sp.-9 controlled disease upto 14 per cent when applied as seed treatment and Trichoderma sp.-11 controlled disease upto 12.6 per cent when applied as drenching.

In general, highest pre-emergence disease control (64.5\%) obtained when Trichoderma sp.-2 and post-emergence disease control
(68.1\%) obtained when Trichoderma sp.-9 applied as biopriming. Similarly, the Trichoderma sp.-2 isolate was also most effective in in vitro screening as it inhibited 67.8 per cent mycelial growth of $R$. solani in dual culture and its volatile metabolites inhibited pathogen growth up to 42.4 per cent. Similarly, in summer season, Rai and Basu (2014) conducted a field experiment with $T$. viride and $P$. fluorescens bio-primed okra seeds and observed that $T$. viride improved plant length, pod length, pod diameter and seed yield.

\section{Acknowledgements}

Research facilities and financial assistance provided for this study by the Department of Plant Pathology, CSKHPKV, Palampur is gratefully acknowledged.

\section{References}

Barnet, H.L. and Hunter, B.B. 1972. Illustrated Genera of Imperfect fungi. Burgess publishing company, Minneapolis, Minnesota, p 165.

Bhat, K.A. 2017. A new agar plate assisted slide culture technique to study mycoparasitism of Trichoderma sp. on Rhizoctonia solani and Fusarium oxysporum. Int.J.Curr.Microbiol.App. Sci. 6: 3176-3180.

Claydon, N., Allan, M., and Hanson, J.R. 1987. Antifungal alkyl pyrones of Trichoderma harzianum. Trans. Br. mycol. Soc. 88: 503-513.

Dennis, C. and Webster, J. 1971b. Antagonistic properties of speciesgroups of Trichoderma-II. Production of volatile antibiotics. Trans. Br. mycol. Soc. 57: 41-48.

Dennis, C. and Webster, J. 1971c. Antagonistic properties of speciesgroups of Trichoderma-III. Hyphal interaction. Trans. Br. Mycol. Soc. 57: 
363-369.

Diwakar, M.P., Rajput, J.C., and D’Souza, T.F. 1986. Diseases of okra in Konkan region of Maharashtra. Pesticides 20: 3-34.

Elad, Y., Chet, I., Boyle, P. and Henis, Y. 1983. Parasitism of Trichoderma spp. on Rhizoctonia solani and Sclerotium rolfsii-scanning electron microscopy and fluorescence microscopy. Phytopathology 73: 85-88.

El-Mohamedy, R.S.R. 2004. Bio-priming of okra seeds to control damping off and root rot diseases. Ann. Agri. Sci. (Cairo) 49(1): 339-356.

Erayya Kumar, J., Shukla, N., Arzoo, K. and Kumar, S. 2018. In viro screening of Trichoderma spp. for their antagonism against soil-borne fungi. Ann. $\mathrm{Pl}$. Protec. Sci. 26: 332-336.

Jandaik, S., Thakur, P. and Kumar, V. 2015. Efficacy of cow urine as plant growth enhancer and antifungal agent. Advances in Agriculture http://dx.doi.org/10.1155/2015/620368

Jalal, A.M., Sulaiman, E.D. and Lashi, N.B. 2019. The effect of water extract of Ocimum basilicum and the fungal biocontrol agent Trichoderma harzianum on fungi causing dampingoff of okra. Rafidain Journal of Science 20(7): 12-27.

Jiskani, M. M., Pathan, M. A., Wagan, K. H., Imran, M. and Abro, H. 2007. Studies on the control of tomato damping-off disease caused by Rhizoctonia solani Kuhn. Pak. J. Bot. 39: 2749-2754.

Jukte, S.R., Badgujar, S.L., Suryawanshi, A.P., Dey, U. and Kuldhar, D.P. 2016. Symptomatology, isolation, identification and pathogenicity test of damping off disease in okra. Int. J. Pl. Protec. 9: 358-361.

Junaid, J.M., Dar, N.A., Bhat, T.A., Bhat, A.H. and Bhat, M.A. 2013. Commercial biocontrol agents and their mechanism of action in the management of plant pathogens. Int. J. Modern Plant \& Anim. Sci. 1: 39-57.

Kamala, T. and Devi, S.I. 2012. Biocontrol properties of indigenous Trichoderma isolates from North-east India against Fusarium oxysporum and Rhizoctonia solani. Afr. J. Biotechnol. 11: 84918499.

Kubicek, C.P. and Harman, G.E. 1998. Trichoderma and Gliocladium volume 1: Basic Biology, Taxonomy and Genetics. Taylor \& Francis Ltd, London, p 3-31.

Kucuk, C. and Kivanc, M. 2003. Isolation of Trichoderma spp. and determination of their antifungal, biochemical and physiological features. Turk. J. Biol. 27: 247-253.

Matny, O.N. 2013. First report of damping-off of okra caused by Phytophthora nicotianae in Iraq. Pl. Dis. 97: 558.

Michrina, J., Michalikova, A., Rohacik, T. and Kulichova, R. 1995. Antibiosis as a possible mechanism of antagonistic action of Trichoderma harzianum against Fusarium culmorum. OchranaRostlin- UZPI 31: 177-184.

Nene, Y.L. and Thapliyal, P.N. 1993. Evaluation of fungicides. In: Fungicides in Plant Disease Control. Oxford and IBH Publishing Company, New Delhi, p 531.

Rai, A.K. and Basu, A.K. 2014. Pre-sowing seed bio-priming in okra: response for seed production. The Bioscan 9: 643647.

Raut, I., Calin, M., Vasilescu, G., Doni, M.B., Sesan, T. and Jecu, L. 2014. Effect of non-volatile compounds of Trichoderma spp. against Fusarium graminearum, Rhizoctonia solani and Pythium ultimum. Rev. Chim. (Bucharest) 65: 1285-1288.

Sharma, N. 2011. Etiology and eco-friendly management of damping off of okra. 
M.Sc. thesis, CSK Himachal Pradesh Krishi Vishvavidyalaya, Palampur, p. 34.

Schalchli, H., Hormazabal, E., Becerra, J., Michael, B., Marysol, B., Marysol, A., Vidal, J. and Quiroz, A. 2011. Antifungal activity of volatile metabolites emitted by mycelial cultures of saprophytic fungi. Chemistry and Ecology 27: 503-513.

Singh, V., Upadhyay, R.S. and Singh, B.R. 2016. Seed bio-priming with
Trichoderma asperellum effectively modulate plant growth promotion in pea. Int. J. Agric., Environ. Biotechno. 9: 361-365.

Tapwal, A., Thakur, G., Chandra, S. and Tyagi, A. 2015. In-vitro evaluation of Trichoderma species against seed borne pathogens. Int. J. Chem. Biol. Sci. 1: 14-19.

Vincent, J.M. 1947. Distortion of fungal hyphae in the presence of certain inhibitors. Nature 159: 850.

\section{How to cite this article:}

Jaina V. Patel, Amar Singh, Khushwinder Kaur, Divya Bhandhari and Banyal, D. K. 2019. Biological Control of Damping Off of Okra caused by Rhizoctonia solani. Int.J.Curr.Microbiol.App.Sci. 8(12): 2277-2292. doi: https://doi.org/10.20546/ijcmas.2019.812.270 